\title{
Isolation and Characterization of Flavobacterium johnsoniae from Farmed Rainbow Trout Oncorhynchus mykiss
}

\author{
Rungkarn Suebsing and Jeong-Ho Kim* \\ Department of Marine Bioscience, Gangneung-Wonju National University, Gangneung 210-702, Korea
}

\begin{abstract}
Flavobacterium johnsoniae was isolated from farmed rainbow trout Oncorhynchus mykiss in Korea, and its biochemical and molecular characterization was determined. Yellow-pigmented bacterial colonies were isolated from 18 of 64 fish samples (28.1\%) on trypticase soy agar plates, and their biochemical profiles were characterized by API 20E and API 20NE test kits. F. johnsoniae was identified by biochemical phenotyping of factors including rapid gliding motility, Gram-negative condition, oxidase- and catalase-positive status, Congo red absorption, nitrate reduction, $\beta$-galactosidase production, acid production from glucose, and gelatin and casein hydrolysis. PCR and subsequent sequencing of $16 \mathrm{~S}$ rRNA confirmed that the yellow-pigmented colonies were most similar to $F$. johnsoniae. The alignment analysis of 16S rRNA sequences also showed that all 18 rainbow trout isolates had highly similar homologies (97-99\% identity). One isolate was selected and named FjRt09. This isolate showed 98\% homology with previously reported $F$. johnsoniae isolates, and in phylogenetic analysis was more closely grouped with $F$. johnsoniae than with $F$. psychrophilum, F. columnare, or $F$. branchiophilum. This is the first report on the occurrence and biochemical characterization of $F$. johnsoniae isolated from rainbow trout in Korea.
\end{abstract}

Key words: Flavobacterium johnsoniae, Oncorhynchus mykiss, Rainbow trout, PCR

\section{Introduction}

Flavobacterium johnsoniae (formerly Cytophaga johnsonae) belongs to a large, diverse group of aerobic Gramnegative bacteria known as the Cytophaga-FlavobacteriumBacteroides group (Bernardet et al., 1996). F. johnsoniae commonly exists in soil and is also frequently isolated from the external lesions of several fish species (Flemming et al., 2007). Generally, F. johnsoniae is not considered a serious fish pathogen, but the species has been associated with several disease outbreaks. For example, F. johnsoniae infection in farmed barramundi Lates carcalifer with 2-5\% mortality was reported in Australia (Carson et al., 1993). Thereafter, these bacteria have been found in Atlantic salmon Salmo salar, sea trout $S$. trutta m. trutta and brown trout S. trutta m. lacustris with more than 5\% mortality during outbreaks in Finland
(Rintamäki-Kinnunen et al., 1997). Recently, F. johnsoniae was also isolated from the external lesions of fish from aquaculture systems in South Africa (Flemming et al., 2007).

The rainbow trout Oncorhynchus mykiss is the most important freshwater fish species in aquaculture in Korea, with annual production increasing annually (Yoon, 2008). The species is susceptible to the fish-pathogenic bacteria of the genus Flavobacterium, i. e., F. columnare (Suomalainen et al., 2005), F. psychrophilum (Misaka and Suzuki, 2007), and F. branchiophilum (Ko and Heo, 1997), but F. johnsoniae has not been reported in rainbow trout to date.

The purpose of this study is to report the isolation and characterization of $F$. johnsoniae from farmed rainbow trout in Korea.
Open Access http://dx.doi.org/10.5657/FAS.2012.0083

This is an Open Access article distributed under the terms of the Creative Commons Attribution Non-Commercial License (http://creativecommons. org/licenses/by-nc/3.0/) which permits unrestricted non-commercial use, distribution, and reproduction in any medium, provided the original work is properly cited. pISSN: 2234-1749 eISSN: 2234-1757
Received 4 November 2011; $\quad$ Revised 26 January 2012; Accepted 8 February 2012

*Corresponding Author

E-mail: jhkim70@gwnu.ac.kr 


\section{Materials and Methods}

\section{Fish samples}

Sixty-four juvenile rainbow trout (0.4-0.7 kg body weight) were collected from four hatcheries in Gangwon Province, South Korea, in 2010 for routine disease monitoring. Fish were packed individually in plastic bags, transported to the laboratory, and processed immediately. Gill and kidney tissues were aseptically removed from individual fish and placed in 1.5-mL microcentrifuge tubes.

\section{Isolation of bacteria and biochemical character- ization}

Gill and kidney tissue samples (100 mg each) were homogenized with $0.9 \%(\mathrm{w} / \mathrm{v}) \mathrm{NaCl}$ and then spread on trypticase soy agar (TSA) plates at $15^{\circ} \mathrm{C}$ for 2-7 days. Among the colonies that appeared, yellow-pigmented colonies, characteristic of the genus Flavobacterium, were selected. These colonies were then subcultured on TSA plates at $15^{\circ} \mathrm{C}$ for an additional 2-7 days and examined for biochemical characterization. A presumptive identification was carried out by Gram staining and oxidase and catalase tests, as described by Austin and Austin (2007). Colonies were tested for the presence of flexirubin pigments by being exposed to $10 \mathrm{~N} \mathrm{KOH}$, followed by neutralization with $12 \mathrm{~N} \mathrm{HCl}$. The biochemical characteristics of the bacteria were then determined using API 20E and 20NE kits (BioMerieux, Marcy l'Etoile, France) with incubation at $15^{\circ} \mathrm{C}$ for $48-72 \mathrm{~h}$. The chitinolytic activity (Richter and Pate, 1988), Congo red absorption (Crump et al., 2001), and gelatin and casein hydrolysis (Cepeda et al., 2004) of the colonies were also tested. The published biochemical characteristics of F. columnare, F. psychrophilum, F. johnsoniae, and F. branchiophilum were used as references (Ko and Heo, 1997; Tamaki et al., 2003; Austin and Austin, 2007; Kubilay et al., 2008; Karatas et al., 2010).

\section{Extraction of DNA and amplification of 165 ribo- somal RNA (rRNA) genes}

Genomic DNA was extracted from $5 \mathrm{~mL}$ of cultured bacterial cells by the AccuPrep Genomic DNA Extraction Kit (Bioneer, Daejeon, Korea). Extracted nucleic acids were concentrated to a final concentration of $100 \mathrm{ng} / \mu \mathrm{L}$. PCR targeting the 16S rRNA was conducted using the universal bacteriumspecific primer set, 20F (5'-AGA GTT TGA TCA TGG CTC AG-3') and 1500R (5'-GGT TAC CTT GTT ACG ACT T-3') (Weisburg et al., 1991). PCR was performed using the lyophilized AccuPower PCR PreMix tube (Bioneer) containing 20 $\mu \mathrm{L}$ of reaction mixture, which comprised $25 \mu \mathrm{M}$ of each primer, $5 \mu \mathrm{L}$ of extracted DNA and DEPC-treated water, with a DNA Engine Peltier Thermal Cycler (BioRad, Hercules, CA, USA). Amplification was carried out with an initial cycle at $95^{\circ} \mathrm{C}$ for $5 \mathrm{~min}$, followed by 30 cycles of $95^{\circ} \mathrm{C}$ for $30 \mathrm{~s}, 51^{\circ} \mathrm{C}$ for $1 \mathrm{~min}$, and $72^{\circ} \mathrm{C}$ for $2 \mathrm{~min}$, with a final extension step at $72^{\circ} \mathrm{C}$ for $5 \mathrm{~min}$.

\section{Sequencing and phylogenetic analysis of the $16 \mathrm{~S}$ rRNA genes}

PCR products were purified by an AccuPrep Gel Purification Kit (Bioneer). Then, $10 \mathrm{ng} / \mu \mathrm{L}$ of purified PCR products were directly sequenced (ABI 3730xl; PE Applied Biosystems, Foster City, CA, USA; available at the National Instrumentation Center for Environmental Management, Seoul National University, Korea). The nucleotide sequences of the 16S rRNA genes were aligned with those available in the GenBank database (NCBI) according to Clustal W by MEGA version 4 (Tamura et al., 2007). This alignment was used to infer phylogenetic relationships among the sequences by the neighbor-joining algorithm with bootstrap values determined by 1,000 replicates. The $16 \mathrm{~S}$ rRNA gene sequences of several $F$. psychrophilum, F. columnare, and $F$. branchiophilum strains were included as references, because these species are genetically very close to F. johnsoniae. The nucleotide sequence was deposited in GenBank under accession no. GU461280.

\section{Results and Discussion}

From 64 fish samples, a total of 231 colonies were observed on TSA plates after $72 \mathrm{~h}$ at $15^{\circ} \mathrm{C}$, and 18 fish samples $(28.1 \%)$ from two hatcheries had yellow-pigmented colonies, which were selected for further identification (Table 1). All 18 isolates showed the same biochemical types with characteristics including rapid gliding motility, Gram-negative rods, oxidasepositive, catalase-positive, flexirubin pigment, nitrate reduction, $\beta$-galactosidase-positive, acid production from glucose, Congo red absorption, and hydrolysis of gelatin and casein. Growth occurred with $1 \% \mathrm{NaCl}$ in tryptic soy broth (TSB) but not with $1.5 \% \mathrm{NaCl}$ in $\mathrm{TSB}$ and no growth occurred at $4{ }^{\circ} \mathrm{C}$. The biochemical characteristics of the bacteria are summarized in Table 2.

Table 1. Prevalence of Flavobacterium johnsoniae in rainbow trout collected from four hatcheries in Gangwon Province, Korea

\begin{tabular}{cccc}
\hline \multirow{2}{*}{ Hatchery sites } & \multirow{2}{*}{ No. of samples } & \multicolumn{2}{c}{ Prevalence } \\
\cline { 3 - 4 } & & Gill & Kidney \\
\hline A & 10 & $6(60.0)$ & $6(60.0)$ \\
B & 10 & $0(0)$ & $0(0)$ \\
C & 15 & $0(0)$ & $0(0)$ \\
D & 29 & $12(41.4)$ & $12(41.4)$ \\
Grand total & 64 & $18(28.1)$ & $18(28.1)$ \\
\hline
\end{tabular}

Values are presented as number (\%). 
The amplification of 16S rRNA from all 18 yellow-pigmented colonies showed a band of approximately 1,300 bp (data not shown). Highly conserved sequences (97-99\%) were found among the 18 isolates (Fig. 1), and one isolate was selected and named FjRt09 (GenBank accession no. GU461280). Phylogenetic tree analysis showed that FjRt09 had $98 \%$ homology and grouped more closely with $F$. johnsoniae than with $F$. columnare, F. psychrophilum, and F. branchiophilum (Fig. 2).

Gram-negative yellow-pigmented bacteria belonging to the genus Flavobacterium have been reported from external lesions on fish, e.g., gill erosion, fin or tail rot, and saddlelike lesions (Rintämaki-Kinnunen et al., 1997). However, the symptoms are usually not specific and sometimes individuals present with no external symptoms. Thus, it is difficult to identify the bacteria, and they are frequently misidentified (Austin and Austin, 2007).

Flavobacterium johnsoniae is known as an opportunistic skin pathogen in certain fish species (Carson et al., 1993). Rintämaki-Kinnunen et al. (1997) showed that brown trout with lesions caused by this bacteria have a high risk of mortality, which can be accelerated by high water temperature

Table 2. Phenotypic characteristics of Flavobacterium johnsoniae isolate from rainbow trout in Korea

\begin{tabular}{|c|c|c|c|c|c|}
\hline Characteristics & FjRt09 & F. columnare & F. psychrophilum & F. branchiophilum & F. johnsoniae \\
\hline Colony pigment & $\mathrm{Y}$ & GY & $\mathrm{Y}$ & LY & $\mathrm{Y}$ \\
\hline Gram reaction & - & - & - & - & - \\
\hline Morphology & Rods & Rods & Rods & Rods & Rods \\
\hline Gliding motility & + & + & $(+)$ & - & + \\
\hline \multicolumn{6}{|l|}{ Production of: } \\
\hline Catalase & + & + & + & + & + \\
\hline Oxidase & + & + & + & + & + \\
\hline Flexirubin-type pigment & + & + & + & - & + \\
\hline Congo red absorption & + & + & - & NA & $\mathrm{V}$ \\
\hline Nitrate reduction & + & + & - & - & + \\
\hline$\beta$-Galactosidase & + & - & $\mathrm{V}$ & - & + \\
\hline Arginine dihydrolase & - & - & - & - & - \\
\hline Lysine decarboxylase & - & - & - & - & - \\
\hline Ornithine decarboxylase & - & - & - & - & - \\
\hline Urease production & - & - & - & - & - \\
\hline Tryptophane deaminase & - & - & - & - & - \\
\hline Indole & - & - & - & - & - \\
\hline Voges Proskauer reaction & - & - & - & - & + \\
\hline $\mathrm{H}_{2} \mathrm{~S}$ production & + & + & - & - & + \\
\hline \multicolumn{6}{|l|}{ Degradation of: } \\
\hline Casein hydrolysis & + & + & + & + & + \\
\hline Gelatin degradation & + & + & + & + & + \\
\hline \multicolumn{6}{|l|}{ Utilization of: } \\
\hline Citrate utilization & - & - & - & - & + \\
\hline \multicolumn{6}{|l|}{ Acid production from: } \\
\hline Glucose & + & - & - & + & $\mathrm{V}$ \\
\hline Mannitol & - & - & - & - & - \\
\hline Inositol & - & - & - & - & _- \\
\hline Sorbitol & - & - & - & - & - \\
\hline Rhamnose & - & - & - & - & - \\
\hline Sucrose & - & - & - & + & - \\
\hline Melibiose & - & - & - & + & - \\
\hline Amygdalin & - & - & - & - & - \\
\hline Arabinose & - & - & - & $(+)$ & - \\
\hline
\end{tabular}

F. columnare data from Tamaki et al. (2003); Kubilay et al. (2008), F. psychrophilum data from Tamaki et al. (2003); Austin and Austin (2007), F. branchiophilum data from Austin and Austin (2007); Ko and Heo (1997), F. johnsoniae data from Tamaki et al. (2003); Karatas et al. (2010).

-, negative response; +, positive response; (+), weak or delayed positive response; Y, yellow; GY, greenish yellow; LY, light yellow; $V$, variable among strains; NA, not available data. 


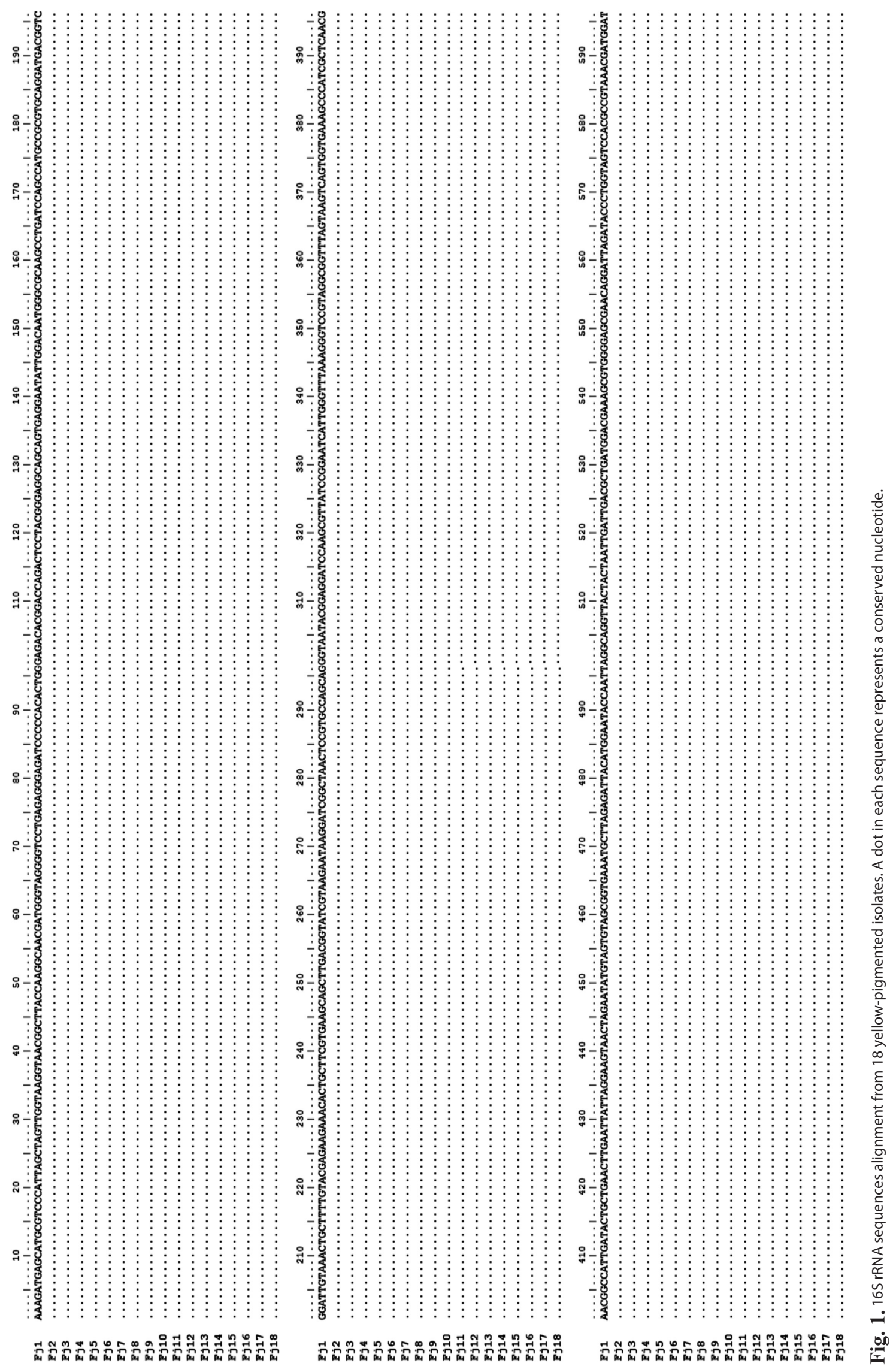




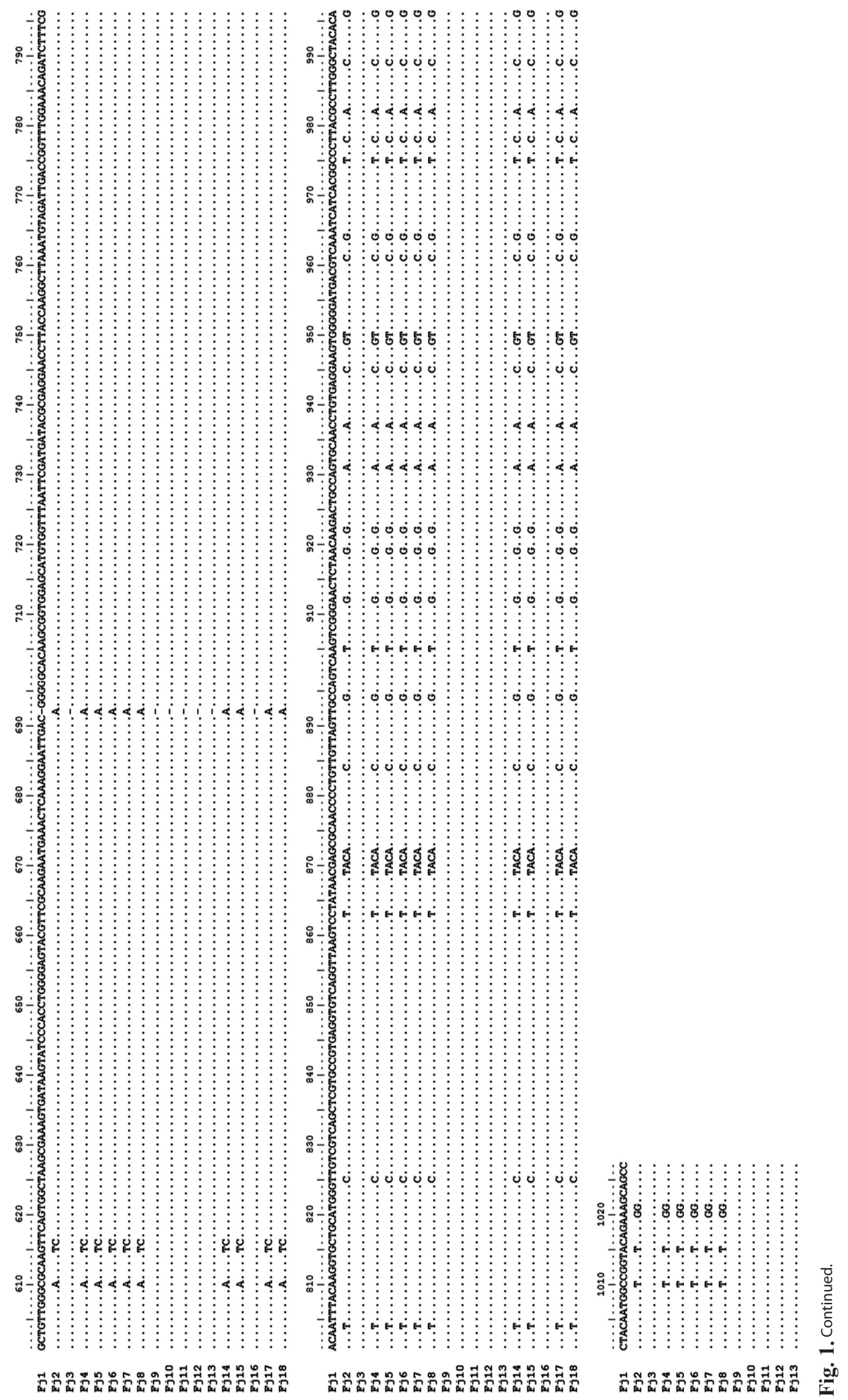




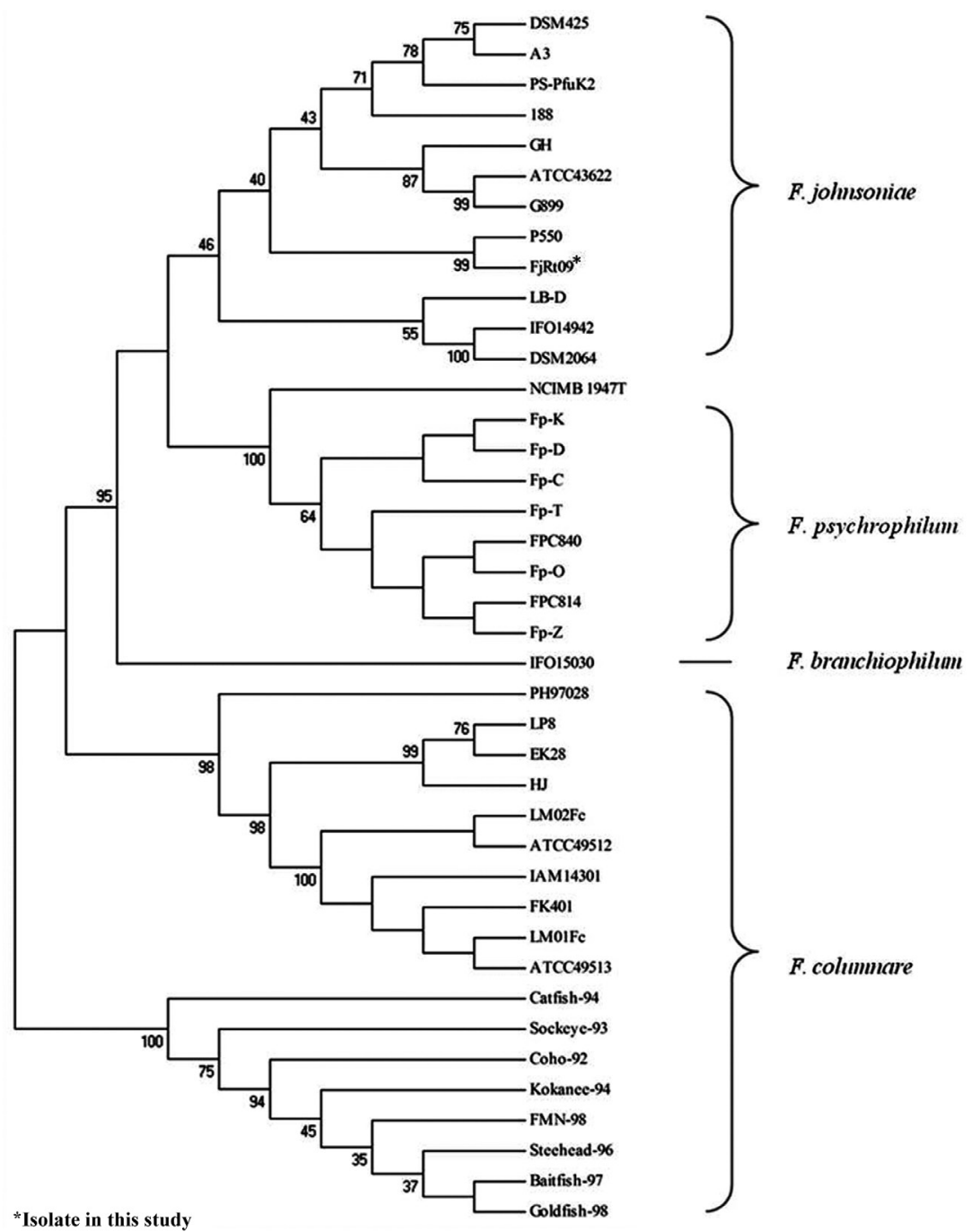

Fig. 2. The phylogenetic tree showing the genetic relationships of Flavobacterium columnare, F. psychrophilum, F. branchiophilum, F. johnsoniae and FjRt09 (accession no. GU461280) isolates based on the 16S rRNA gene sequences. The numbers on the branches are bootstrap values with 1,000 replicates.

and rearing density. F. johnsoniae has been detected in barramundi, Atlantic salmon, sea trout, brown trout, brook trout, and even in the freshwater environment (Carson et al., 1993; Rintämaki-Kinnunen et al., 1997; Hahn et al., 2004; Clark et al., 2009; Seo et al., 2009). However, there has been no report of the isolation of $F$. johnsoniae from rainbow trout to date. Hence, this is the first report documenting $F$. johnsoniae in rainbow trout. Of the four hatcheries tested, two were found to harbor F. johnsoniae, based on rainbow trout gill and kidney samples. It is still unclear if these bacteria strains are pathogenic to rainbow trout in those hatcheries, because the susceptibility of rainbow trout to infection by these bacterial isolates was not tested in this study. F. johnsoniae can be opportunistic under certain conditions, such as a sudden change in water temperature, stress caused by handling, or negative environmental factors (Carson et al., 1993; Karatas et al., 2010).
In this study, 18 out of 64 rainbow trout sample plates developed yellow-pigmented colonies. The affected samples originated from two hatcheries, although the fish showed no external clinical signs. Biochemical characterization was conducted on the 18 yellow-pigmented colonies, and the biochemical characteristics of the bacterial isolates corresponded to those of F. johnsoniae (Carson et al., 1993; Karatas et al., 2010). PCR and subsequent sequencing of $16 \mathrm{~s}$ rRNA genes also identified all 18 yellow-pigmented colonies as $F$. johnsoniae with similarities of $97-99 \%$; thus, one strain was selected and named FjRt09. A phylogenetic tree based on 16s rRNA gene sequences was constructed for FjRt09 and other F. johnsoniae, F. columnare, F. psychrophilum, and F. branchiophilum. The phylogenetic tree demonstrated that the FjRt09 strain clustered in the F. johnsoniae group and shared a branch with F. johnsoniae P550 isolated from brook trout in the United 
States (Clark et al., 2009). It remains unclear how FjRt09 shares a close relationship with P550, and it would be interesting to investigate the relationship between these isolates from geographically distant areas, because there have been no further reports of $F$. johnsoniae in the Asia-Pacific region to date. Moreover, the pathogenic potential of the F. johnsoniae isolate in Korea also needs to be studied.

\section{Acknowledgments}

This research was supported by the Marine and Extreme Genome Research Center Program of the Ministry of Land, Transportation and Maritime Affairs, Republic of Korea.

\section{References}

Austin B and Austin DA. 2007. Bacterial Fish Pathogens: Diseases of Farmed and Wild Fish. Springer-Praxis, Chichester, UK, pp. 112121.

Bernardet JF, Segers P, Vancanneyt M, Berthe F, Kersters K and Vandamme P. 1996. Cutting a Gordian knot: emended classification and description of the genus Flavobacterium emended description of the family Flavobacteriaceae, and proposal of Flavobacterium hydatis nom. nov. (basonym, Cytophaga aquatilis Strohl and Tait 1978). Int J Syst Bacteriol 46, 128-148.

Carson J, Schmidtke LM and Munday BL. 1993. Cytophaga johnsoniae: a putative skin pathogen of juvenile farmed barramundi, Lates calcarifer (Bloch). J Fish Dis 16, 209-218.

Cepeda C, García-Márquez S and Santos Y. 2004. Improved growth of Flavobacterium psychrophilum using a new culture medium. Aquaculture 238, 75-82.

Clark SE, Jude BA, Danner GR and Fekete FA. 2009. Identification of multidrug efflux pump in Flavobacterium johnsoniae. Vet Res 40, 55.

Crump EM, Perry MB, Clouthier SC and Kay WW. 2001. Antigenic characterization of the fish pathogen Flavobacterium psychrophilum. Appl Environ Microbiol 67, 750-759.

Flemming L, Rawlings D and Chenia H. 2007. Phenotypic and molecular chacracterisation of fish-borne Flavobacterium johnsoniae-like isolates from aquaculture systems in South African. Res Microbiol $158,18-30$

Hahn MW, Stadler P, Wu QL and Pöck1 M. 2004. The filtration-acclimatization method for isolation of an important fraction of the not readily cultivable bacteria. J Microbiol Methods 57, 379-390.

Karatas S, Ercan D, Steinum TM, Turgay E, Memis D and Candan A. 2010. First isolation of a Flavobacterium johnsoniae like bacteria from cultured Russian sturgeon in Turkey. J Anim Vet Adv 9, 1943-1946.

Ko YM and Heo GJ. 1997. Characteristics of Flavobacterium branchiophilum isolated from rainbow trout in Korea. Fish Pathol 32, 97-102.

Kubilay A, Altun S, Diler O and Ekici S. 2008. Isolation of Flavobacterium columnare from cultured rainbow trout (Oncorhynchus mykiss) fry in Turkey. Turk J Fish Aquat Sci 8, 165-169.

Misaka N and Suzuki K. 2007. Detection of Flavobacterium psychrophilum in chum salmon Oncorhynchus keta and virulence of isolated strains to salmonid fishes. Fish Pathol 42, 201-209.

Richter CA and Pate JL. 1988. Temperate phages and bacteriocins of the gliding bacterium Cytophaga johnsonae. J Gen Microbiol 134, 253-262.

Rintamäki-Kinnunen P, Bernardet JF and Bloigu A. 1997. Yellow pigmented filamentous bacteria connected with farmed salmonid fish mortality. Aquaculture 149, 1-14.

Seo LJ, Park SH and Lee GH. 2009. Microbiological water quality of water purifiers at elementary school in Gunsan area. Korean J Microbiol 45, 74-81 (in Korean with English Summary).

Suomalainen LR, Tiirola MA and Valtonen ET. 2005. Influence of rearing conditions on Flavobacterium columnare infection of rainbow trout, Oncorhynchus mykiss (Walbaum). J Fish Dis 28, 271-277.

Tamaki H, Hanada S, Kamagata Y, Nakamura K, Nomura N, Nakano K and Matsumura M. 2003. Flavobacterium limicola sp. nov., a psychrophilic, organic-polymer-degrading bacterium isolated from freshwater sediments. Int J Syst Evol Microbiol 53, 519-526.

Tamura K, Dudley J, Nei M and Kumar S. 2007. MEGA4: Molecular Evolutionary Genetics Analysis (MEGA) software version 4.0. Mol Biol Evol 24, 1596-1599.

Weisburg WG, Barns SM, Pelletier DA and Lane DJ. 1991. 16S ribosomal DNA amplification for phylogenetic study. J Bacteriol 173, 697-703.

Yoon GH. 2008. Aquaculture in Korea. Aquac News 34, 16-17. 